\title{
INTERNAL MARKET ORIENTATION AND ITS INFLUENCE ON THE SATISFACTION OF CONTACT PERSONNEL
}

Vicent Tortosa, Universitat Jaume I (Castellon de la Plana) Miguel A. Moliner, Universitat Jaume I (Castellon de la Plana) Javier Sánchez, Universitat Jaume I (Castellon de la Plana)

\author{
Correspondence: \\ Vicent Tortosa \\ Departamento de Administración de Empresas y Marketing \\ Universitat Jaume I \\ Campus del Riu Sec \\ 12071 Castellón de la Plana (Spain)
}

Tlf: +00 34964728548

e-mail: vtortosa@emp.uji.es

Type of paper: Research Paper 


\title{
INTERNAL MARKET ORIENTATION AND ITS INFLUENCE ON THE SATISFACTION OF CONTACT PERSONNEL
}

Keywords: Internal Marketing, Internal Market Orientation (I.M.O.), Stakeholder

Orientation, Satisfaction of contact personnel.

\begin{abstract}
Purpose: To verify the dimensions, reliability and validity of Internal Market Orientation (I.M.O.) as a scale of measurement of internal marketing, and using it to measure the effect of internal marketing on the satisfaction of contact personnel.

Design/Methodology/ Approach: interviews were carried out with all the cashiers of the 16 branches of a small, local credit institution.

Findings: The results show the validity and reliability of the I.M.O. construct, formed by four of the five dimensions of the original scale. They also corroborate the causal relationships among the four dimensions, as well as the significant influence of the informal dimension of I.M.O. on the satisfaction of contact personnel.

Research limitations/Implications: the main limitation of this study is that it analyses a single financial entity, with the characteristics and behaviours that the latter has in its relationship with its employees.

Practical implications: To achieve their organizational objectives, firms must adopt an orientation towards the employee, or internal marketing, on an equal plane to the traditional consideration of the external market. Also, the measurability of this internal orientation on the basis of the I.M.O. scale makes available a valuable tool of planning and control in its implementation.

Originality/value of the paper: this article verifies the validity and reliability of the Internal Market Orientation construct (I.M.O.), and its influence on the satisfaction of contact personnel, in a different business sector and with a different research subject from those analysed hitherto by the literature. It also demonstrates the sequential type of relationship among the dimensions that form Internal Market Orientation.
\end{abstract}




\section{INTERNAL MARKET ORIENTATION AND ITS INFLUENCE ON THE SATISFACTION OF CONTACT PERSONNEL}

\section{Introduction}

The demanding competitive environment is causing firms to consider agents or entities other than customers or competitors as key elements in the working of the organisation. The workforce is one of the agents with the greatest influence on the results of any entity, which confers upon it an unprecedented strategic importance (Post, Preston, \& Sachs, 2002). Indeed, differentiation among firms can be based on the performance of their personnel in the process of production and commercialisation of the good or in the final provision of the service (Gummesson, 1987; Lings, 2004; Lings \& Brooks, 1998).

This reality explains the current trend of marketing research into the sphere of internal organisation (a priority marked by the Marketing Science Institute for the period 2004-06). Precisely on the basis of the theoretical reference constituted by Stakeholder Orientation, orientation towards employees and their treatment as internal customers of the organisation has become the subject of study of the so-called internal marketing (Collins \& Payne, 1991; Rafiq \& Ahmed, 1993).

In this line, different contributions centred on the services sector defend the adoption of internal marketing, favouring the satisfaction of the contact personnel and their greater commitment to constructing fruitful relationships with external customers (Rogers, Clow, \& Kash, 1994; Schneider \& Bowen, 1985). This relationship between internal marketing and the workforce's better attitude is justified on the basis of the theoretical principle of the "psychological contract" (Rousseau, 1990). However, the lack of agreement among the scientific community as to what is understood by internal marketing explains the multitude of definitions that have appeared since its beginnings (Rafiq \& Ahmed, 1993), making it difficult to reach a consensus regarding the most 
suitable scale of measurement to define the concept of internal marketing (Gounaris, 2006). This study, on the basis of the definition by Rafiq and Ahmed (2000), adopts the scale of measurement of Lings and Greenley (2005), known as Internal Market Orientation (I.M.O.), as in our opinion it is the one that best captures the nature of the concept.

Altogether, among the objectives to be achieved by the present investigation is the analysis of the dimensionality of I.M.O. in the financial sector, represented by a small, local credit cooperative, which has the need to apply marketing as an approach to the personnel (Internal Marketing) to be able to compete with the big financial entities or the online banking, across improving the relationship between employees and their clients (the relational banking). We also wish to verify the causal relationships that may exist between the dimensions that form Internal Market Orientation, ending by analysing the possible causal relationships between these dimensions of I.M.O. and the satisfaction of the contact personnel.

\section{Theoretical framework: stakeholder orientation}

The so-called Stakeholder Orientation began with the contributions of a group of researchers characterised by their defence of the necessity for businesses to become oriented towards the different agents with whom they interact as a guarantee of success (Cornell \& Shapiro, 1987; Freeman, 1984; McGuire, Sundgren, \& Schneeweis, 1988; Preston \& Sapienza, 1990). It was Freeman (1984) who formulated the most widely accepted definition of the term Stakeholder Orientation, identifying it as that feature of organisational culture characterised by giving priority to the need to achieve a satisfactory equilibrium among the different entities or agents who contribute and take risks in the course of the business. 
Among the agents or stakeholders that can have a generic influence on a firm we can highlight investors (shareholders), suppliers, customers, the community and, of course, employees (Murphy, Stevens, \& McLeod, 1997). The most traditional Stakeholder Orientation defends the two-way relationship between the firm, represented by its managers, and each of the stakeholders or agents with whom it interacts (Donaldson \& Preston, 1995).

The two-way treatment of Stakeholder Orientation remained current until the appearance this millennium of the so-called New Stakeholder Vision (Post, Preston, \& Sachs, 2002). This new approach is situated within the relationship paradigm, which currently dominates in the marketing area, as it defends the requirement to establish a network structure of interactive relationships in which the different agents interact with each other, the firm becoming the central element of the network. The challenge that the firm must face is to develop, maintain and integrate favourable relationships with the different stakeholders.

Altogether, both in the traditional two-way approach of Donaldson and Preston (1995) and in the relationship approach of Post, Preston, and Sachs (2002) the employees constitute one of the groups of stakeholders that have most influence on the organisation. Consequently, both of them question the traditional external orientation defended by marketing. For all these reasons, Stakeholder Orientation constructs the conceptual framework on which employee orientation rests from a marketing perspective, known as internal marketing (Bitner, Booms, \& Mohr, 1994; Cobb, Samuels, \& Sexton, 1998).

\section{Internal marketing}

Among the first contributions to consider internal aspects of the firm as an integral part of marketing we can highlight the studies by Kotler (1972) and Booms and Bitner 
(1981), though it was the literature on services marketing that gave the necessary impulse to internal marketing as a subject of scientific analysis. Notable in this line is the contribution by Grönroos (1984) and his interactive marketing, in which external marketing or customer focus is related to internal marketing or orientation towards contact personnel. Thus it is argued that the proper management of contact personnel leads to an improvement of employee-customer interaction, and thereby achieves success in the external market (Azzolini \& Shillaber, 1993; Bak et al., 1994; Foreman \& Money, 1995; George, 1990; Gummesson 1987; Lings, 1999; Morgan, 1990; Piercy \& Morgan, 1990, 1991).

Despite this notable start, in recent decades numerous very different definitions of the concept have been posited, showing the great confusion existing as to what exactly it means, how it is supposed to be done, and who is supposed to do it (Ahmed \& Rafiq, 1995; Rafiq \& Ahmed, 1993).

In their classification of the different currents of definitions that have arisen in the literature, Rafiq and Ahmed (2000) consider three distinct branches according to the aim or objective to be achieved: (a) internal marketing as a way of achieving employee satisfaction; (b) internal marketing as a means of achieving customer orientation on the part of employees; and (c) internal marketing as a method for managing change and implementing strategy (table 1).

\section{INSERT TABLE 1}

The idea defended by the first branch of definitions is mentioned indirectly by Sasser and Arbeit (1976), who first maintained that competitive advantage in the services market lies in achieving the satisfaction and motivation of employees, this being a necessary requisite for them to offer a good service to the customer. It was, however, Berry (1981) who first coined the term "internal marketing" to define the 
management behaviour that aims to achieve the satisfaction of employees, by treating them like customers and considering work as an internal product, on the nature of which will depend the improvement in quality of the service offered by the workers to external customers.

The importance given by these studies to the satisfaction of contact personnel is justified by the notion that what the consumer is really paying for when s/he receives a service is the work of the contact personnel who are attending him/her (Parasuraman, Zeithaml, \& Berry, 1985; Schneider \& Bowen, 1985). Implementing a marketing-type orientation at the internal level achieves the much-desired satisfaction of the front-line employee; even further, it attracts, develops, motivates and retains the employees best qualified for the work (Berry \& Parasuraman, 1991). However, according to the latter authors it is necessary for the consideration of the workers as internal customers, and the design of jobs as products towards them, always to be consistent with the objectives of the organisation.

Despite criticisms of the appropriateness of using the term "customer" to denote employees, due to the coercive character of the employment relationship (Mudie, 2003; Rafiq \& Ahmed, 1993), it cannot be denied that there is a link between the internal and external environments of a firm. The satisfaction of the employees thus becomes a key element in the process of creating value for the external customer, achieving his or her satisfaction, retention and long term financial success (Gounaris, 2006; Lings \& Greenley, 2005).

The second branch of definitions of the internal marketing concept focuses on the belief that employees can be motivated to strive to develop a market orientation, to be aware of the needs and demands of external customers, and to acquire a sales mentality through the application of the principles and philosophy of external marketing, and not 
by the traditional approach of the personnel department (Grönroos, 1985; Richardson \& Robinson, 1986). Thus it is considered that through internal marketing the firm can promote the need to have a market orientation among its employees (Barnes, 1989; Papasolomou-Doukakis \& Kitchen, 2004; Quester \& Kelly, 1999).

Customer orientation must be encouraged among all the employees of the organisation, and not be restricted only to those interacting directly with customers (contact personnel), as all the workers who intervene in the preparation and commercialisation of the good or in the provision of the service affect the results of the business (Gummesson, 1987). This requirement is described by means of the concept of Internal Customer Orientation (Lings, 2004), which connects internal marketing with Total Quality Management (T.Q.M.), by maintaining that in any process of delivery of a good or service the employee always has a customer who receives the fruit of his work, whether internal (a worker who receives a good or service from another employee, before him/her in the value chain) or external (end customer). With this orientation, the firm achieves a quality throughout the process which is transferred to the good or service offered to the final customer (Bhote, 1991; Brooks, Lings, \& Botschen, 1999; Frost \& Kumar 2000; Gummesson, 1987; Lings, 2004; Lings \& Brooks, 1998; Lukas \& Maignan, 1996). The same internal customer-supplier logic can go beyond the boundaries of an organisation and be considered in the relationships between departments of different firms. This is known as inter-organisational internal marketing (Lings, 2000).

The third branch of definitions broadens the internal marketing concept, considering the focus on the employee as a vehicle for strategic implementation and change (Winter, 1985). The development of internal marketing as a vehicle of implementation rests on the belief in its potential to integrate the functions within a firm 
(Flipo, 1986; George, 1990; Gilmore \& Carson, 1995; Tansuhaj, Wong, \& McCullough, 1987). This new meaning of internal marketing permits action against resistance to change among the workforce (Darling \& Taylor, 1989; Rafiq \& Ahmed, 1993). Altogether, these authors consider internal marketing as a holistic management process that integrates the many functions of any organisation.

This conception of internal marketing also identifies it as the management of the knowledge demanded by the so-called learning organisation, a term denoting the firm that seeks learning and renewed knowledge as the principal source of competitive advantage (Ballantyne, 2003; Cahill, 1995; Varey \& Lewis, 1999).

Finally, we would highlight the definition by Rafiq and Ahmed (2000, p.454) of the concept of internal marketing, which they consider to be: "the planned effort, using marketing as an approach to the worker, that permits organisational resistance to change to be overcome, and is able to align, motivate, interfunctionally coordinate and integrate employees towards the effective implementation of funcional and corporate strategies, so as to achieve the satisfaction of the external customer through a process that will make possible satisfied, motivated and customer oriented employees".

These authors' definition is the richest and most complete, as it embraces the different branches of definitions that have appeared in the literature since it began. The elements forming it constitute the next challenges to the scientific community, with regard to verifying its validity for delineating the nature of the internal marketing concept. The internal marketing concept, therefore, must first be considered as a form of labour management based on a marketing perspective, with the objective of achieving satisfied and motivated workers.

Most empirical studies focussed on internal marketing are at this first stage of the research, making use of their own operational construct to represent that management of 
personnel whose aim is to achieve a positive attitude and behaviour on the part of the contact personnel (Ahmed, Rafiq, \& Saad, 2003; Foreman \& Money, 1995; Lings \& Greenley, 2005; Tansuhaj, Wong, \& McCullough, 1987).

According to Gounaris (2006), outstanding among all these operational variables is the one used by Lings \& Greenley (2005), called Internal Market Orientation (I.M.O.), as it captures most efficiently the nature of the concept and best overcomes the traditional enumeration of human resources management activities shown by other constructs. For this reason, our study adopts the scale of measurement of internal marketing of Lings \& Greenley (2005), applied to a different business sector and with a different research subject from the ones studied by these authors.

\section{Internal market orientation (i.m.o.)}

The I.M.O. of Lings and Greenley (2005) is an adaptation of the Market Orientation (M.O.) of Kohli and Jaworski (1990) to the context of manager-employee exchanges in the internal market of the organisation. The I.M.O. construct is thus constituted by five dimensions: (a) the informal generation of internal information not previously planned by the managers; (b) the formal generation of internal written information, through questionnaires, surveys, etc.; (c) the formal face to face generation of internal information, through interviews and meetings planned in advance by managers; (d) the dissemination or communication by managers to their employees of the internal information generated; and (e) the design and implementation of the managers' response in accordance with the internal information generated and communicated.

Lings and Greenley (2005) empirically confirm the validity and reliability of the five dimensions that form the construct, in the business sector of retail commerce and with the store managers as research subject. The authors themselves, however, posit the 
need to corroborate the I.M.O. construct in other business sectors and with another subject of research.

In this sense, the present study focuses on another sector, finance, represented by a locally based credit cooperative, and investigates another subject, the cashiers of all the branches of this entity.

Due to the absence in small financial institutions of formal written techniques for obtaining internal information (surveys, questionnaires, etc.), and in line with the arguments of contributions centred on internal organisational communication (Johlke \& Duhan, 2000; Johlke et al., 2000; Mohr \& Nevin, 1990; Stohl \& Redding, 1987), this study only distinguishes formal and informal generation of internal information as representative dimensions of the manner in which managers can obtain information from employees.

For all these reasons, we establish the following as the first hypothesis to be tested:

$H_{1}$ : Internal Market Orientation is a multidimensional construct formed by four dimensions: (1) informal generation of internal information; (2) formal generation of internal information; (3) dissemination of internal information; and (4) response to the internal information generated.

One of the future lines of research enunciated by Lings and Greenley (2005) centres on the need to corroborate the possible causal order of the dimensions of Internal Market Orientation. These authors take the position defended by several studies in Market Orientation, where the three dimensions of M.O. (generation, dissemination and response to the information) are related to each other following a causal order, first being the generation of information, which subsequently influences dissemination, and 
finally the response made to the information generated (Deshpandé \& Zaltman, 1982; Diamantopoulos \& Hart, 1993; Kohli \& Jaworski, 1990; Slater \& Narver, 1995).

On applying this linear model of information processing to the sphere of internal organization, we put forward the following hypotheses for testing:

$\mathrm{H}_{2}$ : The informal generation of internal information directly, positively and significantly influences its subsequent dissemination within the organisation.

$H_{3}$ : The formal generation of internal information directly, positively and significantly influences its subsequent dissemination within the organisation.

In the same line, the generation of internal information may by itself affect the response or action taken by managers towards their contact personnel, irrespective of whether it has first been distributed or communicated (Deshpandé \& Zaltman, 1982; Lings \& Greenley, 2005). We therefore establish as hypotheses to be tested:

$H_{4}$ : The informal generation of internal information directly, positively and significantly influences managers' subsequent response to the contact personnel..

$H_{5}$ : The formal generation of internal information directly, positively and significantly influences managers' subsequent response to the contact personnel.

Finally, the information provided to the contact personnel may determine managers' behaviour, obliging them to behave in a manner coherent with what they communicated earlier (Diamantopoulos \& Hart, 1993; Slater \& Narver, 1995). In this way we justify the following hypothesis:

$H_{6}:$ The dissemination of internal information directly, positively and significantly influences managers' subsequent response to the contact personnel.

\section{Consequences for the satisfaction of contact personnel}

Job satisfaction, also called employee satisfaction, can be defined as a pleasurable or positive emotional state resulting from the appraisal of one's job or job experiences 
(Locke, 1976, p.1300). To portray it operationally, the satisfaction of the contact personnel is taken as an overall construct of the latters' feelings about their work, without entering into consideration of the different facets or dimensions that might form it (Babin \& Boles, 1996; Bagozzi, 1980; Homburg \& Stock, 2005; Johlke \& Duhan, 2000).

One of the aspects most studied by the scientific community is that of the possible antecedents that significantly influence the satisfaction of the contact personnel. In this sense the influence that managers can exercise over the latter is justified on the basis of the theoretical principle of the psychological contract, a set of beliefs held by the worker regarding the reciprocal obligations existing between him and his managers (Morrison \& Robinson, 1997; Robinson \& Rousseau, 1994; Rousseau, 1990).

The contact personnel's valuation of the fulfilment of the obligations, and therefore of the psychological contract, is based on the so-called Theory of Equity (Adams, 1963), which maintains that in every social exchange relationship each participant values the equity of what is offered by one party, called input, against what is received from the other party, called output. So, if the contact personnel consider that the level of outputs exceeds that of inputs they will be under the obligation to reciprocate by increasing the level of inputs that they deliver (higher quality in the exercise of their work, better attitude to customers, etc.).

Among the outputs most highly valued by the contact personnel are direct, fluid, two-way communication with their managers (Johlke \& Duhan, 2000; Johlke et al., 2000; Lester, Claire, \& Kickul, 2001; Thomson \& Hecker, 2000) and the perception of managerial support of them and of their work (Babin \& Boles, 1996; Bell, Menguç, \& Stefani, 2004; Sergeant \& Frenkel, 2000; Wayne, Shore, \& Liden, 1997; Yoon, Beatty, \& Suh, 2001; Yoon, Seo, \& Yoon, 2004). 
The managerial consideration and the direct communication between managers and workers form part of employee orientation or internal marketing, so their application by the business should contribute to the positive reciprocal response of the contact personnel, in the form of greater satisfaction with their work (Aryee, Budhwar, \& Chen, 2002; Rogers, Clow, \& Kash, 1994; Thomson \& Hecker, 2000).

All this leads us to put forward the last hypothesis, to be tested empirically:

$H_{7}$ : The Internal market orientation (I.M.O.) perceived by the contact personnel has a direct, positive and significant influence on their satisfaction.

The model that we propose in this study therefore aims to demonstrate the dimensions, reliability and validity of the Internal Market Orientation construct (I.M.O.), corroborating the causal relationships existing among the dimensions of this construct, and the possible influence of these dimensions on the satisfaction of contact personnel (figure 1).

\section{INSERT FIGURE 1}

\section{Survey methodology}

On the basis of the literature review, an analysis of a qualitative type was carried out in order to identify the principal characteristics of the entity being studied, and thus to be able to adapt more precisely the scale of measurement of I.M.O. Specifically, preparatory interviews were carried out with two top managers of the entity analysed, two of its branch managers, and four cashiers. As a result of this study we opted to differentiate the obtaining of information into two dimensions, formal and informal generation, as proposed by the literature (Johlke \& Duhan, 2000; Mohr \& Nevin, 1990).

For the design of the remaining variable included in the model (the satisfaction of the contact personnel), we used the scale shown in Hunt, Chonko, and Wood (1985) and in Johlke and Duhan (2000), as we can see in table 2. 
The quantitative study was carried out during the months of April and May 2006 in the cities of Castellon and Benicasim (Spain), where all the branches of the credit cooperative studied are located. The investigation was addressed to the cashiers of each of the entity's 16 branch offices. The total number of responses obtained was 27 out of a possible 29; one response was invalidated as it was incomplete, and the other was not presented as one of the employees was off sick. The questionnaire was structured with closed questions and a Likert- type response scale of 7 points.

In the analysis of the data, partial least sequares (PLS) were used (SmartPls 2.0). It has the advantage over LISREL of requiring less stringent assumptions about the randomness of the sample and the normality of the distribution of variables (Wold, 1982). Furthermore, it can accept smaller sizes, as each causal subsystem sequence of paths is estimated separately (Anderson \& Gerbing, 1988; Birkinshaw, Morrison, \& Hulland, 1995; Tsang, 2002; Wold, 1982).

\section{Results of the study}

First, to assure ourselves of the suitability of applying PLS to such a small sample (27 workers), the Cohen's power table for multiple regression (MR) analysis was carried out to calculate the power values of our model. The power values exceeded the minimal level of 0.8 for social sciences (Cohen, 1988).

Generally, PLS results are presented in two stages. In the first stage, the researcher ensures that the measures used as operationalisations of the underlying constructs are both reliable and valid. Once convinced of the adequacy of the measurement model, the researcher can then proceed to interpret the resulting model coefficients (Birkinshaw, Morrison, \& Hulland, 1995).

\section{Analysis of validity and reliability of measures}


The acceptability of the measurement model used here is assessed by looking at the reliability of individual items, the composite reliability, the convergent validity and the discriminant validity.

\section{INSERT TABLE 3}

Individual item reliability is considered adequate when an item has a factor loading that is greater than 0.7 on its respective construct (Carmines and Zeller, 1979). All the item loadings in our final model are above 0.7 (see table 3 ).

Construct reliability anlyses the internal consistency for a given block of reflective indicators. We can use 0.7 as benchmark (Nunnally, 1978). In our research, all the latent constructs are reliable, they all have measures of internal consistency that exceed 0.7. Also, we have checked the significance of the loadings with a re-sampling procedure (500 sub-samples) for obtaining t-stadistic values. They are all significant (see table 3).

Average variance extracted (AVE) assesses the amount of variance that a construct captures from its indicators relative to the amount due to measurement error (Fornell and Larcker, 1981). It is recommended that AVE should be greater than 0,5, so all latent variables of our model exceed this condition (see table 3).

Discriminant validity indicates the extent to which a given construct is different from other latent variables. To assess discriminant validity, square root of AVE should be greater than the correlation between two factors (Barclay, Higgins and Thompson, 1995). In our model, all latent variables satisfy this condition (see table 4).

\section{INSERT TABLE 4}

For all these reasons we accept the first hypothesis, referring to the dimensionality of the scale representing I.M.O.

\section{Analysis of the causal relationships among the variables of the model}


Having established confidence in our measurement model, it is appropriate to now turn to an examination of the structural model. Table 5 shows the hypotheses, path coefficients $(\beta)$ and t-values, which are generated by bootstrapping (500 resamples).

\section{INSERT TABLE 5}

Figure 2 shows a graphical representation of the path coefficients $(\beta)$ and the $R^{2}$ values (variance accounted for) in the dependent variables, which allows a better understanding of the structural model

\section{INSERT FIGURE 2}

The research model seems to have an appropriate predictive powe for all the dependent variables, explaining more tha $75 \%$ of the variance in dissemination of information (0.790); and response to information (0.760). Lower variance shows satisfaction of contact personnel (0.519).

We follow a sequential order in the path analysis, starting the commentary wih the causal relationships among the dimensions of I.M.O. In this sense, of the second to the sixth hypothesis only the fifth is rejected. The seventh hypothesis is also partly demonstrated, as the informal generation of internal information is the only dimension of I.M.O. that has a significant influence on the satisfaction of the contact personnel.

As the results of the causal analysis show, the second hypothesis is accepted, as it shows the great influence $(0.775)$ exerted by the informal generation of information over its subsequent internal dissemination.

The third of the hypotheses is likewise accepted, though the dimension formal generation of internal information shows less influence (0.214) on the dimension dissemination of internal information. So we can consider the greater influence in a local credit cooperative such as the one analysed of the informal generation of internal information on the subsequent dissemination of that internal information. 
The relationship determined by the fourth hypothesis is also accepted, demonstrating the direct influence of the informal generation of internal information on managers' response to that internal information (0.402).

On the other hand, we do not corroborate influence of the formal generation of internal information on the response to this information by managers; the fifith hypothesis proposed by the model is rejected. Therefore, the formal generation of internal information only influences the response through the dissemination of information.

Finally, we refer to the possible influence of the dimensions of I.M.O. on the internal atmosphere of the organization, represented by the satisfaction of the contact personnel. The results partly corroborate the seventh hypothesis, as the informal generation of internal information is the only dimension of I.M.O. that is shown to be an antecedent of the satisfaction of the contact personnel $(0.721)$. On the other hand, the relationship between the other three dimensions of I.M.O. and the satisfaction of the contact personnel is not shown to be significant. The characteristics of the entity studied here may have influenced the results, as its communicative process relies on the relations of an informal character that arise between the managers and the cashiers.

\section{Theoretical and practical contributions}

\section{Theoretical contributions}

The greater protagonism of internal marketing in the literature is justified by the active role that the workforce in any firm, and the contact personnel in the services sector, plays in achieving fruitful relationships with external customers and with the rest of the agents or stakeholders that influence the organisation's activities. This means, according to Stakeholder Orientation, that business manager must orientate themselves towards the internal aspects of the organisation on a plane of equality with the traditional approach to external agents (Greenley and Foxall, 1998). 
The lack of agreement as to the definition of the concept of internal marketing has hampered the greater presence of empirical studies that demonstrate its possible influence on aspects of the organisation's results. In this sense, the present study adopts as its own the definition by Rafiq and Ahmed (2000), considering internal marketing to be that approach by management to the contact personnel that achieves the satisfaction of the customer by means of a process that will make possible employees who are satisfied and motivated in their daily duties.

To be able to corroborate the relationship between internal marketing and the satisfaction of the contact personnel we use the Internal Market Orientation (I.M.O.) of Lings and Greenley (2005) as the scale of measurement of the internal marketing concept. We demonstrate the validity and reliability of the scale in a sector other than that analysed in the literature (financial sector represented by a local credit cooperative), though on the basis of the prior qualitative study it was necessary to adopt four of the five original dimensions, taking only two dimensions, formal and informal generation, to represent the generation of internal information.

The results of the quantitative study show the causal relationship existing among the four dimensions that form I.M.O., so the communicative process follows an ordered sequence, starting with the generation of internal information, continuing with its dissemination, and ending with the response to the information generated and distributed. This relationship is already defended in the literature on Market Orientation (Diamantopoulos and Hart, 1993; Kohli and Jaworski, 1990; Slater and Narver, 1995).

Finally we corroborate the need for management to interact, to maintain a flow of communication with the contact personnel in order to achieve their satisfaction, and thus to improve their attitude and daily behaviour towards external customers. The informal dimension of the communicative process is shown to be the key aspect in the 
manager-cashiers relationship (Johlke and Duhan, 2000; Johlke et al., 2000). The more limited economic and technical possibilities of a small services organisation such as the one analysed explain the primacy of informal communicative practices over those of a formal character.

\section{Contributions to practice}

The increasingly demanding reality of business confirms the need to adopt a Stakeholder Orientation, and with it an approach to employees from a marketing perspective. Internal marketing is even more necessary in the financial sector, where relationship banking and the proper management of the workforce stand out as fundamental aspects in the survival of entities such as local credit cooperatives.

This theoretical justification of internal marketing requires a concrete operational form that can be used by organisations. In this sense, the I.M.O. construct (Lings and Greenley, 2005) can play the role of a practical tool to be used by firms to plan and control the implementation of an orientation towards the employee, based on the communicative process of Kohli and Jaworski (1990), as a management approach to achieve the satisfaction of contact personnel, with which to achieve business success (Berry, 1981; Sasser and Arbeit, 1976).

\section{Limitations and future research}

After mentioning the principal contributions of the study, we show its most notable limitations. First of these is its cross-cutting character, analysing I.M.O. at a given moment in time, when its study demands a longitudinal treatment in accordance with the dynamic nature of the reality that it aims to portray. However, the main limitation of the present study lies in the small number of responses obtained, despite surveying practically all the cashiers of the entity. It is therefore necessary to replicate the study in other financial entities characterised by relationship banking, but of larger size (greater 
number of branches and employees), and therefore with national or international range of action.

Together with the analysis of the financial sector, in future the study of the dimensionality of I.M.O. must be generalised to other activities (within the services sector) and other sectors of the economy (secondary or primary). Another line of research may be the analysis of possible antecedents of orientation towards the employee, and the consequences of the influence of I.M.O. on aspects of the firm's external relationships (quality of service perceived by the customer and the latter's satisfaction). Finally, it is necessary to carry out longitudinal studies of I.M.O. because of the dynamic character of the reality that it portrays, the result of a continuous process of communicative feedback, where the management response to information is a new source of information, beginning again the process that carries the orientation towards the employees. 
Table 1.

Definitions of the internal marketing concept

\begin{tabular}{|c|c|c|}
\hline Authors & Definition & Theoretical approach \\
\hline Sasser and Arbeit (1976); Berry (1981). & $\begin{array}{l}\text { Means of achieving employees' satisfaction by treating them like customers and offering them the job as an internal product that will } \\
\text { permit the quality of service to be improved. }\end{array}$ & $\begin{array}{l}\text { (a) Means of achieving } \\
\text { employee satisfaction. }\end{array}$ \\
\hline Grönroos (1985); Richardson and Robinson (1986). & $\begin{array}{l}\text { Application of a marketing philosophy to motivate employees to have a market orientation, to be aware of customers' needs and } \\
\text { requirements, and to possess a sales mentality. }\end{array}$ & $\begin{array}{l}\text { (b) Way to achieve customer } \\
\text { orientation in employees }\end{array}$ \\
\hline $\begin{array}{l}\text { Parasuraman, Zeithaml and Berry (1985); Schneider and } \\
\text { Bowen (1985); Berry and Parasuraman (1991). }\end{array}$ & $\begin{array}{l}\text { Marketing orientation at internal level to achieve the satisfaction of front-line employees, and to attract, develop, motivate and retain the } \\
\text { best qualified employees. }\end{array}$ & $\begin{array}{l}\text { (a) Means of achieving } \\
\text { employee satisfaction. }\end{array}$ \\
\hline Winter (1985). & Technique of leading employees towards the achievement of organisational objectives. & $\begin{array}{l}\text { (c) Method for management of } \\
\text { change and strategic } \\
\text { implementation. }\end{array}$ \\
\hline Flipo (1986); Tansuhaj, Wong and McCullough (1987). & $\begin{array}{l}\text { Tool of strategic implementation, through coordination, interfunctional communication and reduction of any situation of conflict among } \\
\text { functions. }\end{array}$ & $\begin{array}{l}\text { (c) Method for management of } \\
\text { change and strategic } \\
\text { implementation. }\end{array}$ \\
\hline $\begin{array}{l}\text { Gummesson (1987); Bhote (1991); Lukas and Maignan } \\
\text { (1996); Lings and Brooks (1998); Brooks, Lings and } \\
\text { Botschen (1999); Frost and Kumar (2000); Lings (2004); }\end{array}$ & $\begin{array}{l}\text { Management of internal transactions. This is an approach to Total Quality Management. Each employee is a supplier and customer of } \\
\text { the firm's value chain. The quality of the service or good depends on the quality of the internal transactions occurring among } \\
\text { employees. }\end{array}$ & $\begin{array}{l}\text { (b) Way to achieve customer } \\
\text { orientation in employees }\end{array}$ \\
\hline Barnes (1989). & Strategy for ensuring that the employees are committed to the objective of treating consumers as well as possible. & $\begin{array}{l}\text { (b) Way to achieve customer } \\
\text { orientation in employees }\end{array}$ \\
\hline Darling and Taylor (1989); Rafiq and Ahmed (1993). & Method for overcoming resistance to change among the workforce. & $\begin{array}{l}\text { (c) Method for management of } \\
\text { change and strategic } \\
\text { implementation. }\end{array}$ \\
\hline George (1990); Gilmore and Carson (1995). & $\begin{array}{l}\text { Mechanism of integration among functions in the firm. It is a holistic management process for integrating the different organizational } \\
\text { functions. }\end{array}$ & $\begin{array}{l}\text { (c) Method for management of } \\
\text { change and strategic } \\
\text { implementation. }\end{array}$ \\
\hline Cahill (1995); Varey and Lewis (1999). & Management of the knowledge required by the new organisation or organisation of learning. & $\begin{array}{l}\text { (c) Method for management of } \\
\text { change and strategic } \\
\text { implementation. }\end{array}$ \\
\hline $\begin{array}{l}\text { Quester and Kelly (1999); Papasolomou-Doukakis and } \\
\text { Kitchen (2004). }\end{array}$ & Method of promoting the need to have a market orientation or the concept of service to external customers among the employees. & $\begin{array}{l}\text { (b) Way to achieve customer } \\
\text { orientation in employees }\end{array}$ \\
\hline Lings (2000). & Management of the supplier-internal customer relationship at interorganisational level. & $\begin{array}{l}\text { (b) Way to achieve customer } \\
\text { orientation in employees }\end{array}$ \\
\hline Rafiq and Ahmed (2000). & $\begin{array}{l}\text { Planned effort using marketing as an approach that permits the organisational resistance to change to be overcome, and aligns, } \\
\text { motivates, interfunctional coordinates and integrates employees towards the effective implementation of funcional and corporate } \\
\text { strategies. All of this in order to satisfy the external customer by means of a process that achieves satisfied, motivated and customer } \\
\text { oriented employees. }\end{array}$ & $\begin{array}{l}\text { (a) Means of achieving } \\
\text { employee satisfaction. } \\
\text { (b) Way to achieve customer } \\
\text { orientation in employees. } \\
\text { (c) Method for management of } \\
\text { change and strategic } \\
\text { implementation. }\end{array}$ \\
\hline Ballantyne (2003). & Management of relationships to enable permanent renovation of organisation knowledge. & $\begin{array}{l}\text { (c) Method for management of } \\
\text { change and strategic } \\
\text { implementation. }\end{array}$ \\
\hline Lings and Greenley (2005). & $\begin{array}{l}\text { Organisational Cultura concerned to consider the internal ambience at the same level as the external, with the aim of achieving the } \\
\text { satisfaction of the worker, a key aspect in the progress of the organisation. }\end{array}$ & $\begin{array}{l}\text { (a) Means of achieving } \\
\text { employee satisfaction. }\end{array}$ \\
\hline Gounaris (2006). & $\begin{array}{l}\text { Aspect of the organisational cultura characterised by its commitment to produce value for its employees, by means of effective } \\
\text { management of the relationships between employees, supervisors and top management. }\end{array}$ & $\begin{array}{l}\text { (a) Means of achieving } \\
\text { employee satisfaction. }\end{array}$ \\
\hline
\end{tabular}

Source: own preparation on the basis of the classification criterion shown by Rafiq and Ahmed (2000) 
Figure 1

Causal Model

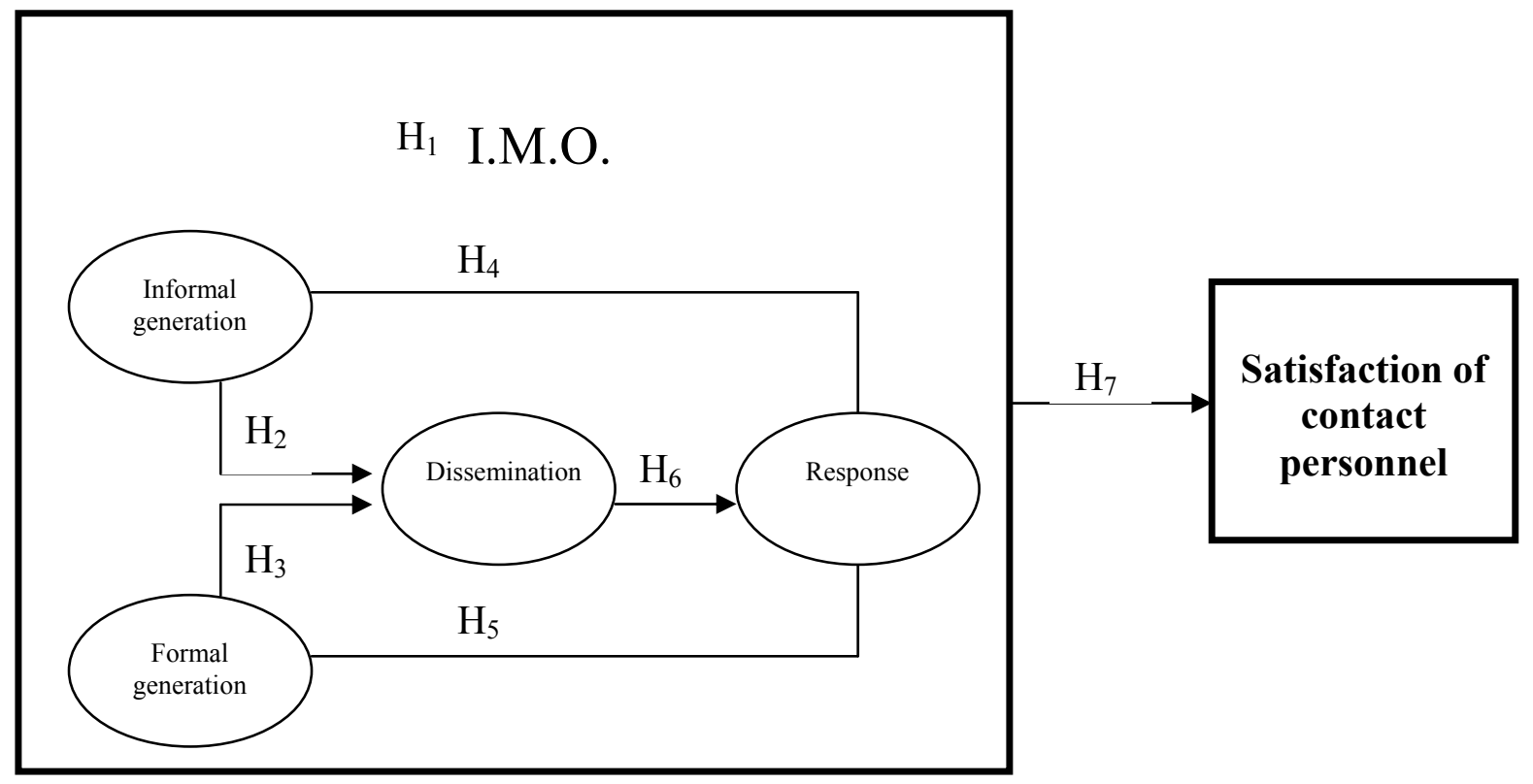


Table 2

Scales of the variables in the model

\begin{tabular}{|c|c|c|c|}
\hline Concept & \multicolumn{2}{|r|}{ Items } & Source \\
\hline \multirow{4}{*}{ Informal generation } & 1.1 & In this office, they try to find out what employees want. & \multirow{16}{*}{$\begin{array}{l}\text { Scale from Lings } \\
\text { and Greenley } \\
(2005)\end{array}$} \\
\hline & 1.2 & $\begin{array}{l}\text { In this office, when an employee is not acting normally, the } \\
\text { managers try to find out if they have a problem. }\end{array}$ & \\
\hline & 1.3 & $\begin{array}{l}\text { In this office they try to find out the employees' true feelings } \\
\text { about their work. }\end{array}$ & \\
\hline & 1.4 & $\begin{array}{l}\text { In this office, the managers often talk to the employees to ask } \\
\text { about aspects of their work. }\end{array}$ & \\
\hline \multirow{3}{*}{ Formal generation } & 2.1 & $\begin{array}{l}\text { In this office there are regular meetings between managers and } \\
\text { employees to discuss matters that the employees wish to address. }\end{array}$ & \\
\hline & 2.2 & $\begin{array}{l}\text { In this office, the managers meet with employees at least once a } \\
\text { year to discuss the employees' future expectations regarding their } \\
\text { work. }\end{array}$ & \\
\hline & 2.3 & $\begin{array}{l}\text { In this office, the managers meet with the employees to try to find } \\
\text { out everything that makes them feel satisfied with their work. }\end{array}$ & \\
\hline \multirow{4}{*}{$\begin{array}{l}\text { Dissemination of } \\
\text { information }\end{array}$} & 3.1 & $\begin{array}{l}\text { In this office, the managers normally meet with the employees to } \\
\text { inform them of matters relating to the organisation (objectives, } \\
\text { strategies,...) }\end{array}$ & \\
\hline & 3.2 & $\begin{array}{l}\text { In this office, the managers normally inform their employees about } \\
\text { aspects affecting their work environment. }\end{array}$ & \\
\hline & 3.3 & In this office, the managers inform all the employees. & \\
\hline & 3.4 & $\begin{array}{l}\text { In this office, the managers inform the employees about work } \\
\text { problems that they have verified earlier. }\end{array}$ & \\
\hline \multirow{5}{*}{$\begin{array}{l}\text { Response to } \\
\text { information }\end{array}$} & 4.1 & $\begin{array}{l}\text { In this office, when the managers find out that their employees are } \\
\text { not happy with their management they take the appropriate } \\
\text { corrective measures. }\end{array}$ & \\
\hline & 4.2 & $\begin{array}{l}\text { In this office, when the managers receive suggestions from the } \\
\text { employees they make an effort to implement them. }\end{array}$ & \\
\hline & 4.3 & $\begin{array}{l}\text { In this office, the managers change their behaviour when the } \\
\text { employees communicate their dissatisfaction. }\end{array}$ & \\
\hline & 4.4 & $\begin{array}{l}\text { After informing the employees, the managers act to improve } \\
\text { working conditions. }\end{array}$ & \\
\hline & 4.5 & $\begin{array}{l}\text { The managers behave in accordance with what employees have } \\
\text { been led to expect. }\end{array}$ & \\
\hline \multirow{6}{*}{$\begin{array}{l}\text { Satisfaction of contact } \\
\text { personnel }\end{array}$} & 5.1 & I feel that my work is valuable. & \multirow{6}{*}{$\begin{array}{l}\text { Scale from Hunt, } \\
\text { Chonko and Wood } \\
(1985) \text {; and Johlke } \\
\text { and Duhan (2000) }\end{array}$} \\
\hline & 5.2 & In my job, I feel that I am doing something that worth. & \\
\hline & 5.3 & I feel that my work is interesting. & \\
\hline & 5.4 & I feel that my work satisfies me. & \\
\hline & 5.5 & If I had to do it again, I would choose this work. & \\
\hline & 5.6 & In general, I am satisfied by my work in this office. & \\
\hline
\end{tabular}


Table 3

Reliability and Convergent Validity

\begin{tabular}{|c|c|c|c|c|c|c|}
\hline Factor & Item & Loading & $\begin{array}{c}\text { t-Value } \\
\text { (Bootstrap) }\end{array}$ & $\begin{array}{c}\alpha \text { de } \\
\text { Cronbach }\end{array}$ & $\begin{array}{l}\text { Composite } \\
\text { Reliability }\end{array}$ & AVE \\
\hline \multirow{4}{*}{$\begin{array}{l}\text { F1. Informal } \\
\text { generation }\end{array}$} & 1.1 & $0.888 *$ & 13.449 & \multirow[t]{4}{*}{0.91} & \multirow[t]{4}{*}{0.939} & \multirow[t]{4}{*}{0.795} \\
\hline & 1.2 & $0.837^{*}$ & 13.295 & & & \\
\hline & 1.3 & $0.940^{*}$ & 50.467 & & & \\
\hline & 1.4 & $0.898^{*}$ & 28.787 & & & \\
\hline \multirow{3}{*}{$\begin{array}{l}\text { F2. Formal } \\
\text { generation }\end{array}$} & 2.1 & $0.889 *$ & 10.290 & \multirow[t]{3}{*}{0.93} & \multirow[t]{3}{*}{0.957} & \multirow[t]{3}{*}{0.882} \\
\hline & 2.2 & $0.962 *$ & 75.407 & & & \\
\hline & 2.3 & $0.962 *$ & 47.503 & & & \\
\hline \multirow{4}{*}{$\begin{array}{l}\text { F3. Dissemination of } \\
\text { information }\end{array}$} & 3.1 & $0.760 *$ & 7.635 & \multirow[t]{4}{*}{0.92} & \multirow[t]{4}{*}{0.945} & \multirow[t]{4}{*}{0.812} \\
\hline & 3.2 & $0.928^{*}$ & 44.253 & & & \\
\hline & 3.3 & $0.952 *$ & 63.543 & & & \\
\hline & 3.4 & $0.950 *$ & 71.500 & & & \\
\hline \multirow{5}{*}{$\begin{array}{l}\text { F4. Response to } \\
\text { information }\end{array}$} & 4.1 & $0.840^{*}$ & 16.321 & \multirow[t]{5}{*}{0.93} & \multirow[t]{5}{*}{0.951} & \multirow[t]{5}{*}{0.795} \\
\hline & 4.2 & $0.932 *$ & 39.487 & & & \\
\hline & 4.3 & $0.849 *$ & 7.584 & & & \\
\hline & 4.4 & $0.941 *$ & 41.142 & & & \\
\hline & 4.5 & $0.891 *$ & 22.736 & & & \\
\hline \multirow{6}{*}{$\begin{array}{l}\text { F5. Satisfaction of } \\
\text { contact personnel }\end{array}$} & 5.1 & $0.843 *$ & 20.075 & \multirow[t]{6}{*}{0.92} & \multirow[t]{6}{*}{0.940} & \multirow[t]{6}{*}{0.726} \\
\hline & 5.2 & $0.920 *$ & 21.197 & & & \\
\hline & 5.3 & $0.783^{*}$ & 9.608 & & & \\
\hline & 5.4 & $0.883^{*}$ & 13.923 & & & \\
\hline & 5.5 & $0.795^{*}$ & 10.614 & & & \\
\hline & 5.6 & $0.877^{*}$ & 23.199 & & & \\
\hline
\end{tabular}

*All t-value are significant at $\mathrm{p}<0.01$ 
Table 4

Discriminant Validity

\begin{tabular}{|c|c|c|c|c|c|}
\hline & F1 & F2 & F3 & F4 & F5 \\
\hline F1 & 0.891 & & & & \\
\hline F2 & 0.332 & 0.939 & & & \\
\hline F3 & 0.867 & 0.549 & 0.901 & & \\
\hline F4 & 0.835 & 0.565 & 0.849 & 0.891 & 0.852 \\
\hline F5 & 0.720 & 0.227 & 0.497 & 0.623 & \\
\hline
\end{tabular}

Note: Diagonal elements are square roots of average variance extracted (AVE), and bellow the diagonal are correlations between factors 
Table 5

Structural model results

\begin{tabular}{|c|c|c|c|c|}
\hline \multicolumn{2}{|c|}{ Hypothesis } & $\beta$ & t-stadistic & $\begin{array}{l}\text { Fulfilment of } \\
\text { hypothesis }\end{array}$ \\
\hline \multicolumn{2}{|c|}{$\mathrm{H}_{2}$ : Informal generation $\rightarrow$ Dissemination of information. } & $0.775^{*}$ & 10.872 & Accepted \\
\hline \multicolumn{2}{|c|}{$\mathrm{H}_{3}$ : Formal generation $\rightarrow$ Dissemination of information. } & $0.214 * *$ & 2.191 & Accepted \\
\hline \multicolumn{2}{|c|}{$\mathrm{H}_{4}$ : Informal generation $\rightarrow$ Response to information. } & 0.402 & 2.038 & Accepted \\
\hline \multicolumn{2}{|c|}{$\mathrm{H}_{5}$ : Formal generation $\rightarrow$ Response to information. } & 0.107 & n.s. & Rejected \\
\hline \multicolumn{2}{|c|}{$\mathrm{H}_{6}$ : Dissemination of information $\rightarrow$ Response to information } & $0.501 * *$ & 2.469 & Accepted \\
\hline $\begin{array}{l}\mathrm{H}_{7}: \text { I.M.O. } \rightarrow \text { Satisfaction of } \\
\text { contact personnel }\end{array}$ & $\begin{array}{l}\text { Informal generation } \rightarrow \\
\text { Satisfaction of contact } \\
\text { personnel }\end{array}$ & $0.721 *$ & 10.530 & Partly accepted \\
\hline
\end{tabular}

Note: $\mathrm{R}^{2}($ dissemination $)=0.790 ; \mathrm{R}^{2}($ response $)=0.760 ; \mathrm{R}^{2}$ ( satisfaction of contact personnel $)=0.519$

$*$ All t-values are significant at $\mathrm{p}<0.01$

$* *$ All t-values are significant at $\mathrm{p}<0.05$ 
Figure 2.

Result of causal relations of the model

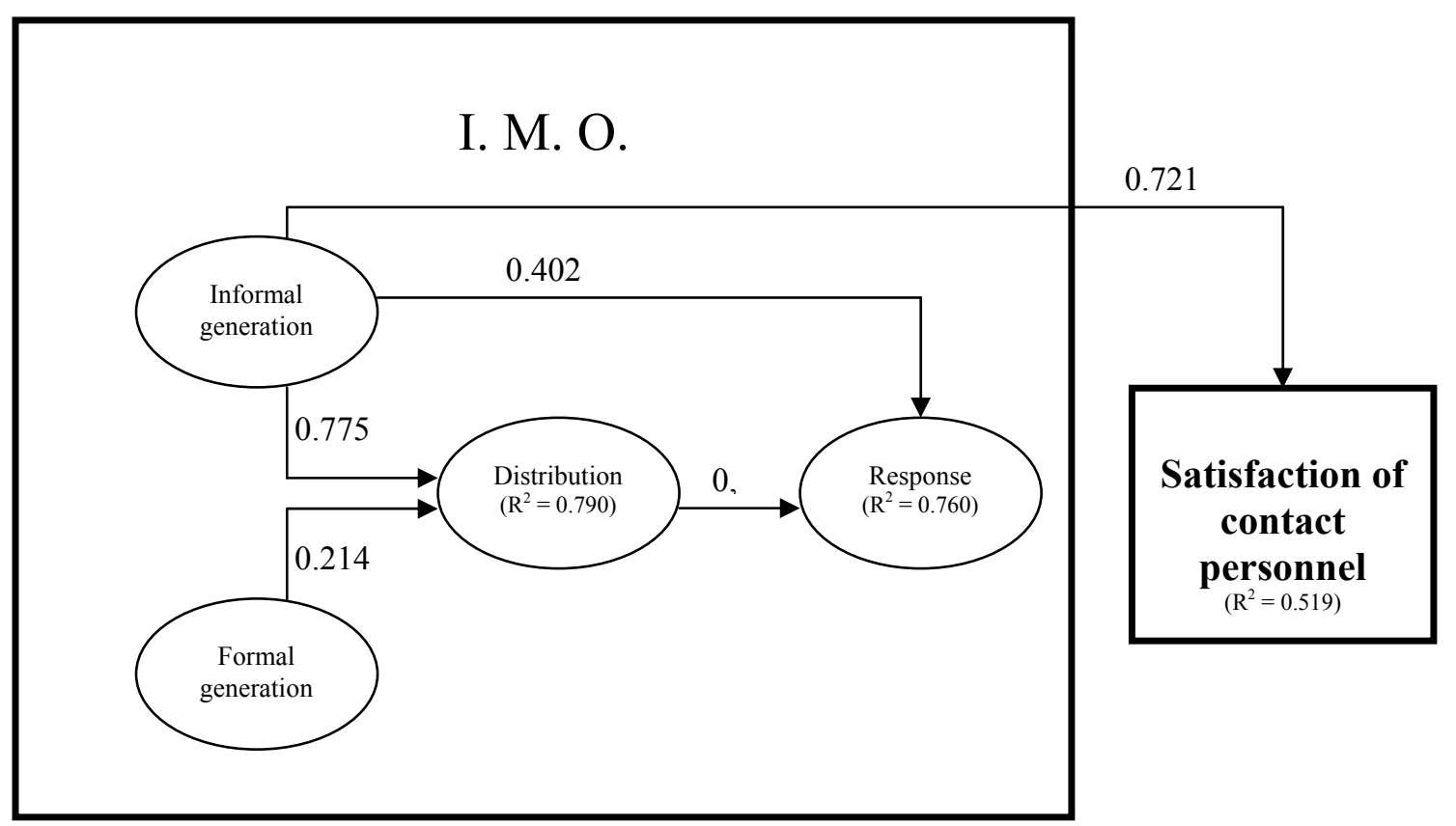




\section{REFERENCES}

Adams, J.S. (1963): "Toward an Understanding of Inequity", Journal of Abnormal and Social Psychology, 67, pp. 422-36.

Ahmed, P. and Rafiq, M. (1995): "The Role of Internal Marketing in the Implementation of Marketing Strategies": Journal of Marketing Practice: Applied Marketing Science, 1(4), pp. 32-51.

Ahmed, P.; Rafiq, M. and Saad, N.Z. (2003): "Internal Marketing and the Mediating Role of Organisational Competencies", European Journal of Marketing, 37(9), pp. 1221-1241.

Anderson, J. C. and Gerbing, D. W. (1988): "Structural Equation Modeling in Practice: A Review and Recommended Two-Step Approach”, Psychological Bulletin, 103(3), pp. 411-423.

Aryee, S.; Budhwar, P.S. and Chen, Z.X. (2002): "Trust as a Mediator of the Relationship between Organizational Justice and Work Outcomes: Test of a Social Exchange Model”, Journal of Organizational Behavior, 23(3), pp. 267-285.

Azzolini, M. and Shillaber, J. (1993): "Internal Service Quality: Winning from the Inside Out", Qualitative Progress, 26(11), pp. 75-78.

Babin, B.J. and Boles, J.S. (1996): "The Effects of Perceived Co-Worker Involvement and Supervisor Support on Service Provider Role Stress, Performance and Job Satisfaction", Journal of Retaling, 72(1), pp 57-75.

Bagozzi, R.P. (1980): "Performance and Satisfaction in an Industrial Sales Force: An Examination of their Antecedents and Simultaneity", Journal of Marketing, 44(2), pp. 65-77.

Bak, C.A.; Vogt, L.H.; George, W.R. and Grenntree, I.R. (1994): "Management by Team: An Innovative Tool for Running a Service Organization through Internal Marketing”, Journal of Services Marketing, 8(1), pp. 37-47.

Ballantyne, D. (2003): “A Relationship-Mediated Theory of Internal Marketing”, European Journal of Marketing, 37(9), pp. 1242-1260.

Barclay, D.; Higgins, C. and Thompson, R. (1995): “The Partial Least Squares (PLS) Approach to Causal Modelling: Personal Computer Adoption and Use as an Illustration", Technology Studies, 2(2), pp. 285-309.

Barnes, J.G. (1989): “The Role of Internal Marketing: If the Staff Won't Buy it Why Should The Customer?", Irish Marketing Review, 4(2), pp. 11-21.

Bell, S. J., Mengüç, B. and Stefani, S.L. (2004): "When Customers Disappoint: A Model of Relational Internal Marketing and Customer Complaints", Journal of the Academy of Marketing Science, 32(2), pp. 112-126.

Berry, L.L. (1981): “The Employee as Customer”, Journal of Retail Banking, 3(1), pp 33-40.

Berry, L.L. and Parasuraman, A. (1991): "Marketing Services: Competing through Quality", The Free Press, New York, NY.

Bhote, K.R. (1991): "Next Operation as a Customer”, Exec. Excellence, (July), pp. 1112. 
Birkinshaw, J.; Morrison, A. and Hulland, J. (1995): "Structural and Competitive Determinants of a Global Integration Strategy", Strategic Management Journal, 16, pp. 637-655.

Bitner, M.J.; Booms, B.H. and Mohr, L.A. (1994): "Critical Service Encounters: The Employee's Viewpoint”, Journal of Marketing, 58(4), pp. 95-106.

Booms, B.H. and Bitner, M.J. (1981): "Marketing Strategies and Organizational Structures for Service Firms", In J. Donnelly y W. George (Eds.), Marketing of Services, American Marketing Association, pp. 47-51, Chicago, IL.

Brooks, R.F.; Lings I.N. and Botschen M.A. (1999): "Internal Marketing and Customer Driven Wavefronts", The Service Industries Journal, 19(4), pp. 49-67.

Cahill, D. (1995): "The Managerial Implications of the New Learning Organization: A New Tool for Internal Marketing", Journal of Service Marketing, 9(4), pp. 43-51.

Carmines, E.G. and Zeller, R.A. (1979): "Reliability and Validity Assessment", Sage University Paper Series on Quantitative Applications in the Social Sciences, 07-017, Sage, Beberly Hills, CA.

Cobb, J.C.; Samuels, C.J. and Sexton, M.W. (1998): “Alignment and Strategic Change: A Challenge for Marketing and Human Resources", Leadership and Organization Development Journal, 19(1), pp. 32-43.

Cohen, J. (1988): "Statistical Power Analysis for the Behavioral Sciences", Lawrence Erlbaum Asssociates ( $\left.2^{\text {nd }} e d\right)$, Hillsdale, NJ.

Collins, B. and Payne, A. (1991): "Internal Marketing: A New Perspective for HRM", European Management Journal, 9(3), pp. 261-270.

Cornell, B. and Shapiro, A.C. (1987): "Corporate Stakeholder and Corporate Finance", Financial Management, 16(1), pp. 5-15.

Darling, R.J. and Taylor, R.E. (1989): “A Model for Reducing Internal Resistance to Change in a Firm's International Strategy", European Journal of Marketing, 23(7), pp. 34-41.

Deshpandé, R. and Zaltman, G. (1982): "Factors Affecting the use of Market Research Information: A Path Analysis", Journal of Marketing Research, 19(1), pp. 14-31.

Diamantopoulos, A. and Hart, S. (1993): "Linking Market Orientation and Company Performance: Preliminary Evidence on Kohli and Jaworski's Framework", Journal of Strategic Marketing, 1, pp. 93-121.

Donaldson, T. and Preston, L.E. (1995): "The Stakeholder Theory of the Corporation: Concepts, Evidence and Implications", Academy of Management Review, 20(1), pp. 65-91.

Flipo, J. P. (1986): "Service Firms: Interdependence of External and Internal Marketing Strategies", European Journal of Marketing, 20(8), pp. 5-14.

Foreman, S.K. and Money A.H. (1995): "Internal Marketing: Concepts, Measurement and Application", Journal of Marketing Management. 11(8), pp. 755-768.

Fornell, C. and Larcker, D.F. (1981): "Evaluating Structural Equation Models with Unobservable Variables and Measurement Error", Journal of Marketing Research, 18, (February), pp. 39-50. 
Freeman, R.E. (1984): "Strategic Management: A Stakeholder Approach", PrenticeHall, Englewood Cliffs, NJ.

Frost, F.A. and Kumar, M. (2000): "INTSERVQUAL- An Internal Adaptation of the GAP Model in a Large Service Organisation", The Journal of Services Marketing, 14(5), pp. 358-371.

George, W.R. (1990): "Internal Marketing and Organizational Behavior: a Partnership in Developing Customer-Conscious Employees at Every Level", Journal of Business Research, 20(1), pp. 63-70.

Gilmore, A. and Carson, D. (1995): "Management Competences for Services Marketing", The Journal of Services Marketing, 10(3), pp. 39-50.

Gounaris, S.P. (2006): "Internal-Market Orientation and its Measurement", Journal of Business Research, 59(4), pp 432-448.

Greenley, G.E. and Foxall, G.R. (1998): "External Moderation of Associations among Stakeholder Orientations and Company Performance", International Journal of Research of Marketing, 15, pp. 51-69.

Grönroos, C. (1984): “A Service Quality Model and Its Marketing Implications”, European Journal of Marketing, 18(4), pp. 36-44.

Grönroos, C. (1985): "Internal Marketing-Theory and Practice", American Marketing Association's Services Conference Proceedings, pp. 41-47.

Gummesson, E. (1987): "Using Internal Marketing to Create a New Culture. The Case of Ericsson Quality", Journal of Business Industry Marketing, 2(3), pp. 23-28.

Homburg, C. and Stock R.M. (2005): "Exploring the Conditions under Which Salesperson Work Satisfaction Can Lead to Customer Satisfaction", Psychology and Marketing, 22(5), pp. 393-420.

Johlke, M.C. and Duhan, D.F. (2000): "Supervisor Communication Practices and Service Employee Job Outcomes", Journal of Service Research, 3(2), pp. 154-165.

Johlke, M.C.; Duhan, D.F.; Howell, R.D. and Wilkes, R.W. (2000): “An Integrated Model of Sales Managers' Communication Practices", Academy of Marketing Science Journal, 28(2), pp. 263-77.

Jöreskog, K.G. and Sörbom, D. (1989): "LISREL 7-A Guide to the Program and Applications", Chicago: SPSS Publications.

Jöreskog, K.G. and Sörbom, D. (1996): "LISREL 8: Structural Equation Modeling with the SIMPLIS Command Language”, Chicago: Scientific Software International.

Kohli, A.K. and Jaworski, B.J. (1990): "Market Orientation: The Construct, Research Propositions and Managerial Implications", Journal of Marketing, 54(2), (April), pp. 1-18.

Kotler, P. (1972): “A Generic Concept of Marketing”, Journal of Marketing, 36(2), (April), pp. 46-54.

Lester, S.W.; Claire, E. and Kickul, J. (2001): "Psychological Contracts in the 21st Century: What Employees Value Most and How Well Organizations are Responding to these Expectations", Human Resources Planning, 24 (1), pp. 10-21.

Lings, I.N. (1999): "Balancing Internal and External Market Orientations", Journal of Marketing Management, 15(4), pp. 239-263. 
Lings, I.N. (2000): "Internal Marketing and Supply Chain Management", Journal of Services Marketing, 14(1), pp. 27-43.

Lings, I.N. (2004): "Internal Market Orientation. Construct and Consequences", Journal of Business Research, 57(4), pp. 405-413.

Lings, I.N. and Brooks, R.F. (1998): "Implementing and Measuring the Effectiveness of Internal Marketing”, Journal of Marketing Management, 14(4/5), pp. 325-351.

Lings, I.N. and Greenley, G.E. (2005): "Measuring Internal Market Orientation", Journal of Service Research, 7(3), pp. 290-306.

Locke, E.A. (1976): "The Nature and Causes of Job Satisfaction", Handbook of Industrial and Organizational Psychology, Rand McNally, Chicago, IL.

Lukas, B.A. and Maignan, I. (1996): "Striving for Quality: The Key Role of Internal and External Customers", Journal of Market Focused Management, 1(2), pp. 175187.

McGuire, J.B.; Sundgren, A. and Schneeweis, T. (1998): "Corporate Social Responsability and Firm Financial Performance", Academy of Management Journal, 31(4), pp. 854-872.

Marketing Science Institute (2004): www.msi.org.

Mohr, J.J and Nevin, J.R. (1990): "Communication Strategies in Marketing Channels: A Theorical Perspectiva", Journal of Marketing, 54(4), pp. 36-51.

Morgan, N.A. (1990): "Implementing Marketing: Key Issues for Professional Service Firms", Journal of Professional Services Marketing, 6(1), pp. 7-16.

Morrison, E.W. and Robinson, S.L. (1997): "When Employees Feel Betrayed: A Model of How Psychological Contract Violation Develops", Academy of Management Review, 22 (1), pp. 226-256.

Mudie, P. (2003): "Internal Customer: by Design or by Default", European Journal of Marketing, 37(9), pp. 1261-1276.

Murphy, B., Stevens, K. and McLeod, R. (1997): “A Stakeholderism framework for measuring relationship marketing", Journal of Marketing Theory and Practice, 5, (Spring), pp. 43-57.

Nunnally, J. (1978): "Psychometric Theory", McGraw-Hill (2 ${ }^{\text {nd }}$ ed.), New York, NY.

Papasolomou-Doukakis, I. and Kitchen, P.J. (2004): "Internal Marketing in UK Banks: Conceptual Legitimacy or Window Dressing?", The International Journal of Bank Marketing, 22(6/7), pp. 421-452.

Parasuraman, A.; Zeithaml, V.A. and Berry, L.L. (1985): "A Conceptual Model of Service Quality and Its Implications for Future Research", Journal of Marketing, 49(4), pp. 41-50.

Piercy, N.F. and Morgan, N.A. (1990): "Internal Marketing: Making Marketing Happen", Marketing Intelligence and Planning, 8(1), pp. 4-6.

Piercy, N.F. and Morgan, N.A. (1991): "Internal Marketing: The Missing Half of the Marketing Programme", Long Range Plann, 24(2), pp. 82-93.

Post, J.E.; Preston, L.E. and Sachs, S. (2002): "Managing the Extended Enterprise: The New Stakeholder View", California Management Review, 45(41), pp, 6-28. 
Preston, L.E. and Sapienza, H.J (1990): "Stakeholder Management and Corporate Performance", Journal of Behavioral Economics, 19(4), pp. 361-375.

Quester, P.G. and Kelly, A. (1999): "Internal Marketing Practices in the Australian Financial Sector. An Exploratory Study", Journal of Applied Management Studies, 8(2), pp. 217-219

Rafiq, M. and Ahmed, P.K. (1993): "The Scope of Internal Marketing: Defining the Boundary between Marketing and Human Resource Management", Journal of Services Marketing, 14(6), pp. 449-462.

Rafiq, M. and Ahmed, P.K. (2000): "Advances in the Internal Marketing Concept: Definition, Synthesis and Extension", Journal of Services Marketing, 14(6), pp. 449-62.

Richardson, B.A. and Robinson, C.G. (1986): "The Impact of Internal Marketing on Customer Service in a Retail Bank", Human Communication Research, 8(2), pp. 170-188.

Robinson, S.L. and Rousseau, D.M. (1994): "Violating the Psychological Contract: Not the Exception but the Norm", Journal of Organizational Behavior, 15(3), pp. 245259.

Rogers, J. D.; Clow, K.E. and Kash, T.J. (1994): "Increasing Job Satisfaction of Service Personnel”, The Journal of Services Marketing, 8(1), pp. 14-26.

Rousseau, D.M. (1990): "New Hire Perceptions of their Own and their Employer's Obligations: A Study of Psychological Contracts", Journal of Organizational Behavior, 11(5), pp. 389-400.

Sasser, W.E. and Arbeit, S.P. (1976): "Selling Jobs in the Service Sector", Business Horizons, 19(3), (June), pp. 61-65.

Schneider, B. and Bowen, D.E. (1985): "Employee and Customer Perceptions of Service in Banks: Replication and Extension", Journal of Applied Psychology, 70(3), pp 423-433.

Sergeant, A. and Frenkel, S. (2000): "When Do Customer Contact Employees Satisfy Customers?”, Journal of Service Research, 3(1), pp. 18-34.

Slater, S.F. and Narver, J.C. (1995): "Market Orientation and the Learning Organization”, Journal of Marketing, 59(3), (July), pp. 63-74.

Stohl, C. and Redding, Ch. (1987): "Messages and Message Exchange Processes", in Handbook of Organizational Communication: An Interdisciplinary Perspective, Jablin et al. (ed.), Newbury Park, CA.

Tansuhaj, P., Wong, J. and McCullough, J. (1987): "Internal and External Marketing: Effect on Customer Satisfaction in Banks in Thailand", International Journal of Bank Marketing, 5(3), pp 73-83.

Thomson, K. and Hecker, L. (2000): "Value-Adding Communication: Innovation in Employee Communication and Internal Marketing", Journal of Communication Management, 5(1), pp. 48-58.

Tsang, E.W.K. (2002): “Acquiring Knowledge by Foreign Partners from International Joint Ventures in a Transition Economy: Learning-by-Doing and Learning Myopia", Strategic Management Journal, 23, pp. 835-854. 
Varey, R.J. and Lewis, B.R. (1999): “A Broaden Conception of Internal Marketing", European Journal of Marketing, 33(9/10), pp. 926-45.

Wayne, S.J.; Shore, L.M. and Liden, R.C. (1997): "Perceived Organizational Support and Leader-Member Exchange: A Social Exchange Perspective", Academy of Management Journal, 40(1), pp. 82-111.

Winter, J.P. (1985): "Getting your House in Order with Internal Marketing: a Marketing Prerequisite", Health Marketing Quarterly, 3(1), pp. 69-77.

Wold, H. (1982): "Systems under indirect observations using PLS", A Second Generation of Multivariate Analysis: Volume 1 - Methods. Praeger chapter 15, Fornell (ed.), New York.

Yoon, M.H.; Beatty, S.E. and Suh, J. (2001): "The Effect of Work Climate on Critical Employee and Customer Outcomes. An Employee-Level Analysis", International Journal of Service Industry Management, 12 (5), pp. 500-21.

Yoon, M.H.; Seo, J.H. and Yoon, T.S. (2004): "Effects of Contact Employee Supports on Critical Employee Responses and Customer Service Evaluation", Journal of Services Marketing, 18 (5), pp. 395-412. 